\title{
Bankruptcy tourism within Russia: issues of jurisdiction in personal bankruptcy cases
}

\author{
Vladislav Silchenko* \\ Ural State Law University, Department of Civil Procedure, 620137, Ekaterinburg, Russia
}

\begin{abstract}
The paper analyzes the practice of the Supreme Court of the Russian Federation in countering bankruptcy tourism of citizens. The paper considers the cases with the criteria for jurisdiction of personal bankruptcy in Russia, and employs the category of the center of main interests of the debtor known to foreign law order. The author shows the difference between the jurisdictional links in Russia and the EU in cases of personal bankruptcy, and general and specific in the presumptions that determine the jurisdiction factors. The paper provides the Russian definition of bankruptcy tourism defined by the Supreme Court of the Russian Federation for cases when a debtor-citizen 'manipulates' the jurisdiction of the bankruptcy case to transfer its consideration to the region where the debtor does not actually live, and shows the legal consequences of these actions in court proceedings. According to the author, in terms of Russian law, the practice of combating bankruptcy tourism does not imply the refusal to protect the rights which a person is abusing, it is based on the specifics of proving the jurisdiction factor - the place of residence of the debtor. The author argues the relevance of the European experience in regulating cross-border insolvency for improving the Russian legislation on bankruptcy.
\end{abstract}

\section{Introduction}

In recent years, Russian courts have faced situations when a debtor-citizen changes the registration data at the place of residence to change the jurisdiction of the bankruptcy case shortly before the creditor submits a bankruptcy application or after filing this application, but before the court accepts it [1]. According to p. 4, Art. 38 of the Code of Arbitration Procedure of the Russian Federation (hereinafter referred to as the APC RF), this jurisdiction is determined by the debtor's address, and according to cl.1, Art. 33 of the Federal Law No. 127-FZ of 26.10.2002 On Insolvency (Bankruptcy) (hereinafter referred to as the Bankruptcy Law) by the place of residence of the debtor (the above norms of the APC RF and the Bankruptcy Law do not contradict each other, although they employ a different categorical apparatus; for convenience, we will use the category 'place of residence of the debtor' to determine the jurisdiction of bankruptcy personal cases of citizens that indicates the fact that the debtor is an individual).

In cross-border insolvency, the situation when the debtor chooses his preferred jurisdiction and justifies it as an optimal insolvency legislation of this jurisdiction is called 'bankruptcy tourism' [2]. This can be called a special case of the phenomenon of 'forum shopping', that is, identifying the optimal jurisdiction for a certain transaction [3].

By virtue of the lex forum concursus link in bankruptcy cases, the choice of jurisdiction determines the law applicable to the bankruptcy case. In turn, forum shopping can be both the result of abuse of the debtor's right and the legitimate choice of a more attractive jurisdiction [4].

However, a change in the territorial jurisdiction of the bankruptcy case within Russia will not change the applicable law, since the debtor remains in the same jurisdiction. But there are motives of a different nature, for example, increased transaction costs for creditors to accompany the case in another region (territorial remoteness from the competent court, which can take on significant scales within Russia) [5].

With regard to the fact that bankruptcy procedures are a collective form of protection of interests [6], any actions of the debtor aimed at infringing of creditors' rights (that is, threatening the protection of collective interests) should entail adequate opposition from the courts. Therefore, the effect of the relocation of the citizen-debtor prior to the initiation of bankruptcy proceedings on his jurisdiction (legal consequences of the relocation of the debtor-citizen) and determination of the place of residence of the debtor-citizen (the specifics of proving the fact) are of high relevance.

\section{Results}

According to p. 1, Art. 47 of the Constitution of the Russian Federation, no one can be deprived of the right to have his case considered by the court and the judge to whose jurisdiction it is attributed by law. As mentioned above, the law states that the bankruptcy case of a person is subject to consideration at the place of his residence. 
The importance of observing these rules of jurisdiction is emphasized by their relationship with the right to a fair trial consolidated in Art. 6 of the 1950 Convention for Protection of Human Rights and Fundamental Freedoms (Rome) [7].

Consequently, any mechanism that leads to the deviation from the jurisdiction rules established by law, which is used as a reaction to a particular behavior of a debtor-citizen, should be assessed in terms of its effect on the constitutional (procedural) right of the debtor to have his case considered a bankruptcy case by the court and the judge to whose jurisdiction it is attributed by law.

The Russian law and order is aware of cases of abusing the right to resolve a case by a specific court, and there is judicial practice to counteract such abuse. The classic example is the refusal to the creditor of the right to choose the jurisdiction of the case on the claim against the main debtor filed at the address of the surety, if the surety agreement was concluded by the creditor with the purpose of changing the jurisdiction. The factors testifying to such abuse of the right, and the mechanism for counteracting it, were described in cl. 6 of the Resolution of the Plenum of the Supreme Arbitration Court of the Russian Federation No. 42 of 12.07.2012 On certain issues of resolving disputes related to surety for arbitration courts, which was applied by the courts of general jurisdiction [8], and today it is consolidated in par. 52 of the Resolution of the Plenum of the Supreme Court of the Russian Federation No. 45 of 24.12.2020.

In terms of the mechanism of counteraction to domestic bankruptcy tourism, it is of interest to consider whether this practice is based on the refusal to exercise procedural law abused by its bearer (as in the example with surety agreements and jurisdiction at the choice of the plaintiff), or whether the solution to the problem has a different basis.

\subsection{Center of main interests of the debtor in Russian judicial practice}

At present, the Russian judicial practice at the level of the Supreme Court of the Russian Federation exhibits four cases with a detailed assessment to the actions of debtors-citizens aimed at changing the jurisdiction of the bankruptcy case: the bankruptcy case of citizen Bazhanov (the Judicial Collegium for Economic Disputes of the Supreme Court of the Russian Federation No. 305-ES18-16327 of 25.02.2019), citizen Chuck (the Judicial Collegium for Economic Disputes of the Supreme Court of the Russian Federation No. 308ES18-25635 of 21.03.2019), citizen Shamir (the Judicial Collegium for Economic Disputes of the Supreme Court of the Russian Federation No. 306-ES193574 of 25.07.2019), citizen Kharchenko (the Judicial Collegium for Economic Disputes of the Supreme Court of the Russian Federation No. 310-ES20-18855 of 25.03.2021).
In these cases, the developed approach of the Russian law enforcer to bankruptcy tourism is described by the following theses.

Firstly, bankruptcy tourism is defined as the creation of artificial conditions for changing the territorial jurisdiction of a bankruptcy case through a formal change of registration for the purpose of preventing creditors from exercising their rights to receive from the debtor the due performance in the insolvency procedure.

Secondly, the bankruptcy case of the debtor-citizen is subject to consideration at the place of his residence but not registration.

Thirdly, it is presumed that the place of residence of the debtor-citizen corresponds to the place of his registration; however, in exceptional cases, such a presumption can be refuted, and the place of residence of the debtor will be established directly. After refuting the presumption, the proof of residence at the place of registration is burdened on the debtor.

In the case of bankruptcy of citizen Chuck, a new category was developed for Russian legislation - 'the center of gravity of the economic interests of the debtor'. The localization of the center of gravity of economic interests the debtor was associated with the location of most of his property, creditors and legal entities with which the debtor had corporate relations, on a certain territory. It should be noted that as a result of the establishment of these factors, the Supreme Court of the Russian Federation recognized not only the center of gravity of economic interests of the debtor, but also the main place of his activity and actual residence, although this idea did not develop (the place of the debtor residence was not associated with the center of gravity of his economic interests).

However, in the bankruptcy case of citizen Shamir, the Supreme Court of the Russian Federation formed its position through other categories: the center of economic interests of a group of companies controlled by the debtor together with partners, the place of concentration of the debtor and his creditors (the place of concentration of their economic interests is the location of property, bank accounts, governing bodies of legal entities), the presence of economic interests of the debtor on a certain territory.

Finally, in the bankruptcy case of citizen Kharchenko, the category of the center of main interests of the debtor was mentioned in the context of identifying the political and legal prerequisites for establishing the jurisdiction of the bankruptcy case at the debtor's place of residence.

Let us focus on the instability of the wording of the Supreme Court of the Russian Federation. In our opinion, this is due to the fact that the Supreme Court of the Russian Federation did not employ the category consolidated in Russian legislation, but implicitly referred to the foreign practice of combating bankruptcy tourism and translated this term in different ways.

The center of main interests of the debtor (COMI) is the jurisdictional link used to determine the competent court in cross-border insolvency. COMI is most extensively used in the European Union (EU), and its regulatory framework is the current Regulation (EU) 
2015/848 of the European Parliament and of the Council of 20 May 2015 on insolvency proceedings (recast) [9].

E.V. Mokhova states that in the EU the mechanism of COMI identification is based on the 'rule of presumption': it is presumed that the location of COMI for legal entities is the country of the registered office of the debtor, for individuals engaged in business or other professional activities, it is the principal place of business, and for other individuals, it is the habitual residence. This presumption is refuted if the place of management of interests of the debtor is on the territory of another country, which is obvious to the creditors of the debtor [5]. It should be noted that the place of management of interests of the debtor, which is obvious to creditors in accordance with Art. 3 of the Regulation (EU) 2015/848, forms COMI.

Par. 30 of the Regulation (EU) 2015/848 comprises the examples of factors that may refute the above presumptions, that is, lead to the immediate (not presumed) establishment of COMI. For example, for citizens who are not engaged in independent business or professional activity, these factors may include: the major part of the debtor's assets is located outside the Member State of the debtor's habitual residence, or where it can be established that the principal reason for moving was to file for insolvency proceedings in the new jurisdiction and where such filing would materially impair the interests of creditors whose dealings with the debtor took place prior to the relocation.

The features of COMI localization in the EU and the features of localization of the center of main interests of the debtor on the territory of the jurisdiction of a particular arbitration court in Russia are very close. They are based on the economic rather than formal legal relations of a person with a certain territory. E.V. Mokhova notes that the EU developments on the use of COMI and minimization of unfair forum shopping are implemented in Russian judicial practice [5].

Thus, in Russian legislation, a model of establishing the jurisdiction factor is similar to that in the EU, that is, with the help of presumed facts. Moreover, in Russia and in the EU (in cases of bankruptcy of citizens who are not engaged in business or other professional activities), a general factor that gives rise to the presumption effect the fact of registration at a certain place of residence. However, the presumed facts are different: the fact of COMI localization in a specific jurisdiction in the EU and the fact of real residence of a citizen on a certain territory in Russia.

The secondary importance of COMI is evident in Russia. The group of facts summarized by the Supreme Court of the Russian Federation as the center of main interests of the debtor (the center of gravity of economic interests of the debtor, etc.) does not determine the jurisdiction of the case; however, as will be shown below, it can affect it.

\subsection{Specificities of proving the debtor's residence}

In the analyzed cases, the Supreme Court of the Russian Federation considered the dishonesty of debtors who relocated in order to 'artificially change the territorial jurisdiction of the case', and the fact that such behavior indicates an abuse of law.

The case of bankruptcy of citizen Shamir was demonstrative, where the Supreme Court of the Russian Federation indicated that if the actual place of residence of the debtor does not correspond to the registration data and the jurisdiction manipulation is assumed, the court must refuse to protect the right to consider the bankruptcy case at the place of registration of the debtor and apply to the dishonest side of the norm, which the debtor was trying to abuse. For this, the norms on the abuse of civil (material) rights were chosen as a legal basis.

In the doctrine, there are various approaches to understanding the abuse of procedural rights, which state that the abuse is the result of a special use of existing law. For example, procedural rights are abused by any person who uses these rights to harm the opposite party, or in any other way that is unacceptable in terms of the fundamental legal values that form the basis for proceedings [10].

There are many measures for countering the abuse of procedural rights. For example, A.V. Yudin divides these measures into two groups: measures of civil procedural responsibility and other measures of civil procedural coercion, which are not measures of responsibility, subdivided into procedural preventive measures and measures of civil procedural protection. Among these measures, the author indicates the refusal to a person to authorize a procedural action, restriction of procedural and other rights of persons when considering a civil case, etc. [11].

The procedural law consolidates such measures for counteracting the abuse of procedural rights as attribution of court costs to the abuser (Art. 111, APC $\mathrm{RF}$ ), refusal to satisfy an application or petition that was not filed in a timely manner due to abuse (p. 5, Art. 159, APC RF). This list of measures is provided in the doctrine and applied in practice (for example, this does not cover a measure of response to a situation with the changed jurisdiction using a surety agreement).

For this study, the question of interest is whether the actions of the debtor aimed at changing the jurisdiction of the bankruptcy case are recognized by the courts as an abuse of procedural rights to consider the case by the court to whose jurisdiction it is attributed by law, while the competence in the bankruptcy case is recognized by the court, where the debtor lived prior to the prebankruptcy period, as a result of the refusal to protect (authorize) this right.

In our opinion, the answer should be negative. All the cases (except for the case of bankruptcy of citizen Shamir, where the Supreme Court of the Russian Federation for some reason came into conflict with its 
own previously expressed positions) indicated that the jurisdiction of the court is associated with the place of residence of the debtor-citizen but not with the place of registration. Thus, if the debtor relocated and did not simulate it, the court at the new place of residence of the debtor will become the competent court for considering the bankruptcy case. In this case, relocation is not recognized as a factor affecting the jurisdiction of the case.

This means that if the court refuses to recognize itself competent to consider the case at the place of registration of the debtor, it must conclude that the debtor does not actually live in this place. At the same time, the debtor did not have any right to consider the case at the place of registration (not residence), therefore, there is no refusal to exercise the right.

The value of the investigated legal position is not in a new understanding of the rules of procedural law on the jurisdiction of bankruptcy cases or on the measures for counteracting the abuse of procedural rights, but in clarifying the rules for proving a specific factor - the place of residence of the debtor-citizen for the purpose of determining the jurisdiction of the dispute. The Supreme Court of the Russian Federation stated in the judicial act on the bankruptcy case of citizen Kharchenko that 'if the person concerned provides convincing arguments and presents evidence that gives rise to reasonable doubts in the court about the correspondence of data on the debtor's registration to the real state of affairs, the person is burdened to confirm that the change in registration data is due to objective reasons and is associated with relocation to another region. COMI is relevant since the facts about real close relation of the debtor with a certain territory can confirm the arguments of interested parties about the inconsistency of the debtor's place of residence with the registration data.

Thus, it is possible to talk about the existence of:

1. presumption of the actual residence of an individual in a certain place, which is affected by registration at a certain place of residence;

2. group of facts that refute the given presumption: the fact that the debtor relocated shortly before the creditor applied to the court to declare the debtor bankrupt and the fact of localization of the center of main interests of the debtor on a territory other than the declared place of residence.

In the doctrine of the legal consolidation, presumptions can be divided into legal and factual [12]. The former presumptions are consolidated in law, while the latter, according to $\mathrm{H}$. Schack, are based on life experience, the prevailing probability of an event [13].

Since the presumption of the coincidence of the place of citizen's residence with the place of his registration was developed by the Supreme Court of the Russian Federation from legislative norms, it should be recognized as legal.

At the same time, the group of facts presented above that is used to refute such a presumption forms a factual presumption. For example, the Supreme Court of the Russian Federation stated that 'relocation prior to the initiation of a bankruptcy case entails a high probability that the debtor's relocation shows the signs of abuse' (bankruptcy case of citizen Kharchenko). In other words, probabilistic judgments acquire legal significance, which are based on the judges' perception of a fair behavior of the debtor in bankruptcy, but not on those based on law.

It is important that the indicated factual presumption is stronger than the legal presumption of residence opposed to it, since it refutes the latter. This refutation leads to the fact that substantiation of the jurisdiction of the case in the court at the place of the debtor's registration is burdened to the debtor.

The debtor can fulfill the burden if he can prove his actual relocation. However, the inconsistency of this approach cannot be neglected.

On the one hand, the debtor is burdened to prove that 'the change in registration data was due to objective reasons and is associated with relocation' (this position was reproduced in each of the cases). Since the only objective reason for changing the registration data may be relocation (Art. 6 of the Law of the Russian Federation No. 5242-1 of 25.06.1993 On the right of citizens of the Russian Federation to freedom of movement, choice of place of stay and residence within the Russian Federation), that the debtor must prove the fact of actual relocation by any means.

On the other hand, in the case of bankruptcy of citizen Bazhanov, the Supreme Court of the Russian Federation indicated examples of such 'objective reasons for the change of registration', namely family circumstances and business activities. However, the above can be considered the reasons for relocation, but not for the changed registration data.

Since the citizens of the Russian Federation are free in their choice of place of residence (p. 1, Art. 27 of the Constitution of the Russian Federation), the presence of objective reasons for relocation should not be recognized as the required fact, as the debtor can in fact relocate without objective reasons. However, this does not exclude the possibility of considering the reasons for relocation as a factor considered by the court when deciding on the reality of the debtor's relocation.

Thus, the approach to combating domestic bankruptcy tourism is based on the application of general rules of proof in the arbitration process, the purpose of which is to find out the actual place of residence of the debtor. Bankruptcy tourism is defined as actions aimed at changing the registration data, that is, in procedural refraction, at the emergence of a presumption of fact, but not the fact-the basis of jurisdiction.

In our opinion, the investigated refutation of the presumption is an ordinary result of the evidentiary activity of the persons involved in the case, and it cannot be considered as a specific negative consequence for the person abusing the right.

\section{Conclusion}

Despite the fact that the debtor's actions to change the registration data at the place of residence are recognized as unfair, they do not affect the jurisdiction factor - the debtor's actual residence, which is emphatically 
separated from the registration address. As a result, the debtor with the changed registration address, who did not actually moved to a new place of residence, has no right to have his case considered by the court and the judge to whose jurisdiction it is attributed. The court at his real place of residence remains the competent court.

However, the changed registration address without relocation has legal significance for the bankruptcy case, since it gives rise to the legal presumption of the debtor's residence at the registration address. At the same time, the rules for proving the place of the debtor's residence developed by the Supreme Court of the Russian Federation are based on the ideas of COMI and prevent the manipulation of the jurisdiction of the case.

Since the approach to determining the jurisdiction of bankruptcy cases of citizens at the place of residence do not have any exceptions, an important issue is posed by E.V. Mokhovoy: should actual relocation of the debtor prior to the initiation of the case on his bankruptcy affect the jurisdiction of the case? [5].

In the studied approach, actual relocation without any exceptions (including relocation due to unlawful motives) will not exclude the competence of the court at the debtor's new place of residence.

A different approach would come into direct conflict with the law, which would lead to a violation of the right guaranteed by the Constitution of the Russian Federation to have the case considered by the court and the judge to whose jurisdiction it is attributed.

However, the fact that the place of residence of the debtor-citizen has become a value concept cannot be ignored. At present, the solution of the practical task of countering bankruptcy tourism lies in the plane of judicial discretion in determining the place that can be considered the place of residence of the debtor.

Although Russian law de jure employs a much more stable and obvious criterion for the jurisdiction of the bankruptcy case (place of residence) than the EU (COMI standard), in practice the legal certainty of participants of Russian bankruptcy cases on the jurisdiction of the case is hardly higher. In our opinion, it is easier to establish the place of management of interests of the debtor, which is obvious to his creditors, instead of looking for a place that can be called the 'actual' place of residence of the debtor without any formalized guidelines.

Thus, although the Supreme Court of the Russian Federation has made significant progress in solving the problem of domestic bankruptcy tourism, which is mainly due to its statement, it can be qualitatively solved only by means of the legislative reform, which, in our opinion, could be based on the European experience of applying COMI as a jurisdictional link.

\section{References}

1. P.M. Morhat, 'Bankruptcy tourism' in Russian judicial practice: the right of a citizen or violation of the interests of creditors, Russian judge, 6 13-17 (2019)

2. J.P. Tribe, Bankruptcy Tourism in the European Union: Myth or Reality? (2016) Retrieved from: https://ssrn.com/abstract $=2781500$ http://dx.doi.org/10.2139/ssrn.2781500.

3. W.G. Ringe, Forum Shopping Under the EU Insolvency Regulation, Oxford Legal Studies Research Paper, 33 (2008). DOI: https://dx.doi.org/10.2139/ssrn.1209822.

4. E.V. Mokhova, N.P. Yatsuk, A.E. Lidzhanova, Forum shopping and regulatory competition in cross-border insolvencies and restructurings, Law, 9, 97-114 (2020)

5. E.V. Mokhova, The Point of Attraction of Economic Interests of an Individual Debtor: The Concept Development in the Russian Court Practice, Law and business, 1, 31-39 (2021)

6. V. V. Yarkov, V. V. Dolganichev, Training of legal specialists in the context of development of collective forms of judicial remedy, Perspectives of Science \& Education, 6, 141 (2020)

7. V.V. Yarkov, Arbitration proceedings: Textbook (Statut, Moscow, 2021) 103 p.

8. V.V. Yarkov, Free judicial variations on procedural law: what to do with them and how to deal with them, Herald of the Economic Justice in the Russian Federation, 3 27-33 (2017)

9. S.A. Karelina, Insolvency (bankruptcy): Training course, vol. 2 (Statut, Moscow, 2019) 752 p.

10. Yu.V. Vede, The Main Concepts of Violation of Procedural Rights, Arbitration and civil process, 10, 19-23 (2019)

11. A.V. Yudin, Abuse of a procedural right in civil proceedings (Lema Publishing House, 2009) pp. 33-39.

12. E.A. Nakhova, The evidentiary presumption as the individual terms of the distribution of responsibilities according to proof in reformed civil legislation, Leningrad legal journal, 1, 173-176 (2014)

13. H. Schack, International Civil Procedural Law (BEK Publishing House, 2001) 326 p. 